\title{
Doctors' dilemma paralyses French medicine
}

Paris. Legislation intended to outlaw conflicts of interest among French physicians in the prescribing of drugs for patients has spread confusion through the medical profession and raised the possibility that biomedical research will suffer. Under a new law passed by the previous Socialist government, physicians who accept any form of payment from drug companies can be fined FF500,000, jailed for two years and struck off for ten. To be safe, physicians have no doubt taken to buying their own ballpoint pens.

The purpose of the law is to discourage physicians from partisan prescribing, considered bad for patients and the health deficit. But medical organizations and the drug companies say the law will also paralyse science. Much of the criticism can be traced to the medical profession's unhappiness at being tainted with suspicion because of the actions of a few.

Controversy centres on an exemption for activities whose "real purpose is research or scientific evaluation". Physicians particularly resent a condition that the Conseil National d'Ordre des Médecins (CNOM) should approve every transaction, protesting that bureaucracy will stifle spontaneity. CNOM, which backs tighter control, has introduced standard contracts and other simplifying measures.

The exemption's real flaw, says Pierre Colombier, a physician at the federation of continued medical training associations UNAFORMEC, is that CNOM's approval will not guarantee immunity from prosecution. "It's not yet clear what's permitted, and what's not," says Jean-François Sfarti, president of Sanofi-Winthrop. Drug companies, which would face stiff penalties as accomplices, say that this ambiguity has left them with no choice but to call a moratorium on scientific activities involving payment or perquisites.

It is too soon to say if the law will adversely affect science. Most of this year's activities were arranged before it came into force, and are unaffected. But the potential for damage is large. The pharmaceutical industry informally sponsors around FF20 billion's worth of scientific activity every year (about FF 100,000 per physician), although Colombier says that much of this goes on marketing exercises.

But the new law will certainly hurt scientific conferences, many of which are sponsored by drug companies, which sometimes pay physicians to attend. Although some are alibis for holidays, most are of high-quality and thus are essential to cross-fertilization between clinicians and researchers. Many conferences have already been cancelled (and hotel labour unions are complaining). The pharmaceutical industry and CNOM are asking that attendance at conferences should be free from control.

Many post-market drug studies (so-called Phase IV trials) will also be hurt, although their scientific value is often dubious. They frequently lack placebo controls or neglect to blind investigators, and appear sometimes designed to acquaint physicians with particular products. There have been cases where physicians can trade a certain number of prescriptions for a case of champagne. Phase I, II and III clinical trials will not be affected, as these are already strictly regulated.

Drug promotion, which the new law all but bans, is a grey area. Physicians need to learn about the latest drugs, and how best to use them. "The possibilities of fraudulent agreements are even more tempting when he who buys the product is neither he who pays, nor he who uses it", reflects Prescrire, a magazine that refuses drug advertising on its pages. CNOM and pharmaceutical unions want the law to be brought into line with a 1992 European directive on the matter, which allows for "reasonable hospitality" (to physicians by drug companies).

The new government has now promised a more flexible interpretation of the law, but major changes would require new legislation and would take time. The government will not wish to be perceived as soft on corruption. So the physicians' dilemma may be resolved less formally. Roger Luccioni, professor of cardiology at the La Temone hospital in Marseilles, has helped create a nonprofit clearing-house for funds from drug companies. Benign neglect of the provisions of the law, as with the recent restrictions on smoking in public places, is another remedy: although the smoking restrictions are not enforced, people appear to be smoking less.

Declan Butler

\section{British group backs French scientist}

London. A British ethics committee has given its support to Jean-Pierre Allain, one of the three specialists from the French National Blood Transfusion Centre (CTNS) currently appealing against their convictions by a Paris court for allowing haemophiliacs to be treated in the mid-1980s with blood infected with HIV.

The committee, chaired by the philosopher Baroness Warnock, has concluded that

\section{IMAGE UNAVAILABLE FOR COPYRIGHT REASONS}

Allain (right) with co-defendants in French AIDS trial.

Allain acted in a way "consistent with medical professional ethics" in warning his superiors of the dangers of allowing haemophiliacs to be given potentially contaminated blood, and urging the rapid adoption of foreign heat-treatment technology.

Allain, who is now a professor of transfusion medicine at the University of Cambridge, has been suspended at his own suggestion as director of the East Anglian regional blood transfusion service while awaiting the outcome of his appeal, expected on 13 July. He has long protested that he has been made a scapegoat for decisions (to dealy the introduction of heat treatment) by his superiors both inside and outside the CTNS (see Nature 363, 491; 1993).

Warnock's committee was set up by the East Anglia Regional Health Authority to decide whether Allain was fit to continue in his position as director of the regional transfusion centre. In a report completed last month - but whose publication was held back until the appeal hearing ended in Paris last week - the committee says that, judging his actions "in the light of the scientific climate of the time", there is "no reason" to regard him as unfit to hold his Cambridge position.

Allain said last week that he felt the committee's conclusions "gives me back my integrity and honour". But he is bitter about the lack of support from his French colleagues, claiming that many of them are "scared" to come to his defence in the light of widespread criticism of their own actions in not warning haemophiliacs of the dangers of untreated blood.

The regional health authority is awaiting the outcome of Allain's appeal before deciding whether he should continue to be suspended from his position with the blood transfusion service. Meanwhile Allain is continuing with his research at the university.
David Dickson 